\title{
A comparison of the effect of forage type and level of feeding on the digestibility and gastrointestinal mean retention time of dry forages given to cattle, sheep, ponies and donkeys
}

\author{
R. A. Pearson ${ }^{1}$, R. F. Archibald ${ }^{1}$ and R. H. Muirhead ${ }^{2}$ \\ ${ }^{1}$ Centre for Tropical Veterinary Medicine, University of Edinburgh, Easter Bush Veterinary Centre, Roslin, Midlothian EH25 9RG, UK \\ ${ }^{2}$ Department of Veterinary Clinical Studies, University of Edinburgh, Easter Bush Veterinary Centre, Roslin, Midlothian EH25 \\ $9 R G, U K$
}

(Received 2 February 2005 - Revised 11 August 2005 - Accepted 11 September 2005)

\begin{abstract}
Four cattle, sheep, ponies and donkeys were fed dehydrated lucerne, early-cut hay, later-cut hay or barley straw in a Latin square-based design for four periods of $35 \mathrm{~d}$. In the first sub-period animals were fed the diets ad libitum (1-21 d) and in the second sub-period they were fed the same diet restricted to 0.75 of ad libitum intake (days 22-35). Measurements of forage intake, apparent digestibilities and gastrointestinal mean retention times (MRT) were made in the last $7 \mathrm{~d}$ of each sub-period. Differences between species in voluntary DM intake (VDMI; g/kg live weight (LW) ${ }^{0.75}$ and $\mathrm{g} / \mathrm{LW})$ were greatest on the lucerne and least on barley straw. Cattle VDMI $\left(\mathrm{g} / \mathrm{kg} \mathrm{LW}^{075}\right)$ compared with intake of the other species was $>$ ponies $>$ sheep $>$ donkeys on lucerne. On barley straw VDMI $\left(\mathrm{g} / \mathrm{kg} \mathrm{LW}^{075}\right)$ of cattle compared with intake of the other species was $=$ donkey $=$ ponies $>$ sheep. VDMI of hays were intermediate between the lucerne and straw forages. Apparent digestibilities of DM, organic matter $(\mathrm{OM})$, neutral-detergent fibre (NDF) and acid-detergent fibre (ADF) of the lucerne and hays were higher in the ruminants than in the equids. Effect of feeding level was not significant. Gastrointestinal MRT was shorter in the equids than in the ruminants. On straw diets donkeys showed similar apparent digestibilities of feed components to those of the cattle, whilst apparent digestibility of the straw diet by the ponies was lowest. Results are discussed in relation to evolutionary differences in feeding and digestion strategy associated with fore- or hind-gut fermentation in ruminants and equids.
\end{abstract}

Apparent digestibility: Forage intake: Equids: Ruminants

The herbivores have been classified according to their methods of ingesting and processing feeds containing varying levels of cellulose and dietary fibre and their preferences during feeding (Hoffman, 1989; van Soest, 1994). The domestic ruminants are classified as 'fore-gut' fermenters and the equids are 'hind-gut' fermenters. In considering the feeding 'preferences' of these herbivores, horses, donkeys and cattle have been classified as 'bulk and roughage eaters' feeding predominantly on leaves, buds, plant stems and large amounts of grass (Hoffman, 1989), whereas goats and sheep are classified as intermediate feeders (Hoffman, 1989; van Soest, 1994). These food-preference classifications are less exact than the classification based on sites of fermentation. It could be argued that the race horse consuming high levels of concentrate feed could be classified as an intermediate feeder (Ellis and Hill, 2005) and in a different category from the donkey consuming only mature grasses and cereal crop residues in the tropical dry season. While some 'intensive' husbandry systems for equids and ruminants are now far removed from their natural grazing environment and include concentrate feed in the daily ration, most sustainable feeding systems throughout the world rely only on grazing and conserved forage diets to supply the animal's nutrient intake for maintenance, growth, pregnancy, lactation or work. In looking at the evolution of the herbivores, the ruminants (sheep, goats and cattle) were thought to possess the competitive advantage of pre-gastric fermentation compared with the non-ruminants (horses, donkeys; Duncan et al. 1990). The equids, it was suggested, had a lower digestive capacity and developed behavioural strategies, horses grazing for 14-16h per d (Duncan, 1980), and donkeys for 14-17 h per d (Smith, 1999) to maintain intake on forage. Cattle in contrast spend only $6-10 \mathrm{~h}$ grazing and $6-8 \mathrm{~h}$ in rumination (Smith, 1999). However, the equids with their mainly postgastric site of fermentation can absorb the available soluble carbohydrate and protein, without potential loss of substrates associated with the microbial processes. However, they will have less opportunity for absorption of microbial digestion endproducts than ruminants. Intake of forage is dependent on a large number of interacting factors. Protein and fibre content of forage are the intrinsic factors affecting intake and digestibility upon which the digestive processes operate,

Abbreviations: ADF, acid-detergent fibre; CP, crude protein; Cr-fibre, Cr-mordanted hay fibre; DMI, DM intake; LW, live weight; LW ${ }^{075}$, metabolic live weight; MRT, mean retention time; NDF, neutral-detergent fibre; OM, organic matter; VDMI, voluntary DM intake.

* Corresponding author: Dr R. Anne Pearson, fax +44 131651 3903, email anne.pearson@ed.ac.uk 
and both gastrointestinal distension and the presence of nutrients in the digestive tract exert controlling effects on feed intake (Allen, 2000; Rhind et al. 2002; Ellis \& Hill, 2005). These physical and physiological factors may vary between fore- and hind-gut fermenters in the relative controlling effects they exert on intake.

Comparative studies of the different species of ruminant, cattle, sheep, goats and/or buffalo have been undertaken to understand how they differ in their ability to digest forages of different quality (for example, Batista et al. 1982; Isac et al. 1994) and similarly comparative studies have been undertaken between the equids (for example, Cuddeford et al. 1995; Pearson et al. 2001). Batista et al. (1982) observed differences in in vitro digestibility of forages by buffalo, zebu cattle and Holstein cattle, with buffalo and zebu being similar and superior to Holstein cattle on good-quality forage; on poor forage (high-fibre, low-protein), buffalo were superior to both the Holstein and zebu animals. Isac et al. (1994) observed no difference in nutrient digestibility between species when sheep and goats were fed lucerne hay or vetch straw, but lower rumen degradabilities of crude protein $(\mathrm{CP})$ and neutral-detergent fibre (NDF) of vetch in goats than in sheep, suggesting possible differences in rumen microbial fermentation in the two species. Comparative studies of the different equids on a restricted ration have shown that donkeys retained feed residues in the gastrointestinal tract longer than did ponies, irrespective of forage type. As a consequence, the donkeys digested fibre more effectively than did ponies (Cuddeford et al. 1995). When allowed forage ad libitum ponies consumed more forage than donkeys, but the higher apparent digestibilites of nutrients by the donkeys enabled them to compensate for their lower intakes of feed (Pearson et al. 2001), again suggesting possible differences in feeding and digestive strategies between the two species. Feeding trials have been undertaken to compare differences between a ruminant species and an equine species in their ability to consume and digest forage diets (for example, Cymbaluk, 1990; Ouedraogo \& Tisserand, 1996; Dulphy et al. 1997a; Menard et al. 2002). Digestibilities of the feed components were generally greater in the ruminant species on hay diets (cattle or sheep) than in horses, and similar on legume hays or mature grasses. Feed intakes seemed to be more closely related to $\mathrm{CP}$ and NDF content of the forage in ruminants than in horses. Comparisons across more than two herbivores have generally been made in reviews which have collated the relevant literature from several trials (for example, Dulphy et al. 1994, 1997b; Lawrence et al. 2001; Smith \& Pearson, 2003); few comparative studies across more than two species of each herbivore type have been conducted under controlled experimental conditions (for example, Udén \& van Soest, 1982). The present experiment was designed to compare the differences between four domestic herbivore species in their ability to consume and digest the same conserved forages from different forage types. One of the forages was perceived to be of low quality (barley straw), one to be of high quality (lucerne) and two of medium quality (from two different swards of temperate meadow hay). The forages were offered at two levels of feeding, ad libitum and a restricted level (about $75 \%$ ad libitum intake). The aim of the experiment was to determine the differences between the species in food intake and digestibility when dry conserved forages were given under the same conditions and feeding environment.

\section{Material and methods}

\section{Experimental design}

Short-chopped $(10-15 \mathrm{~cm})$ dehydrated lucerne produced by Dengie Crops Ltd, Maldon, Essex, short-chopped (20$30 \mathrm{~cm}$ ) barley straw and two temperate grass hays, early-cut 'Gowkley hay' with a lower fibre content than a later-cut (3 weeks later) 'Dunbar hay', from swards from two different farms, were offered to the animals in a $4 \times 4$ Latin square design for periods of 5 weeks. The early-cut hay was harvested from a pasture reseeded 7 years earlier with ryegrasses. Grasses identified in the hay crop were Lolium perenne, Poa trivialis, Dactylus glomerata, Agropyrum repens and Holcus lanatus. The later-cut hay was harvested from a pasture reseeded 4 years before the present study. Grasses identified in the hay crop were Lolium perenne, Poa trivialis, Dactylus glomerata, some Agrostis spp. and Festuca pratensis. The composition of the four forages (Table 1) was determined by standard methods (Association of Official Analytical Chemists, 1990) after sub-sampling diets offered daily. Within each 5-week time period the diets were offered for the first 3 weeks ad libitum and in weeks 4 and 5 at a rate restricted to 0.75 of the average ad libitum intake of each diet.

\section{Animals and their management}

The experiment was carried out at the Centre for Tropical Veterinary Medicine, Edinburgh from May to September 1996. Four 3-year-old castrated Friesian cattle, four 2-3-year-old castrated Scottish Blackface sheep, four 6-10-year-old gelding

Table 1. Composition of diets offered ( $\mathrm{g} / \mathrm{kg} \mathrm{DM}$ )

(Mean values with their standard errors)

\begin{tabular}{|c|c|c|c|c|c|c|c|c|}
\hline & \multicolumn{2}{|c|}{ Lucerne } & \multicolumn{2}{|c|}{$\begin{array}{l}\text { Gowkley hay } \\
\text { (early-cut) }\end{array}$} & \multicolumn{2}{|c|}{$\begin{array}{l}\text { Dunbar hay } \\
\text { (late-cut) }\end{array}$} & \multicolumn{2}{|c|}{ Barley straw } \\
\hline & Mean & SEM & Mean & SEM & Mean & SEM & Mean & SEM \\
\hline DM $(\mathrm{g} / \mathrm{kg})$ & 906 & $2 \cdot 4$ & 901 & 1.6 & 901 & 1.0 & 900 & $1 \cdot 1$ \\
\hline Organic matter & 850 & $5 \cdot 0$ & 893 & $5 \cdot 7$ & 897 & 4.9 & 896 & 4.9 \\
\hline Neutral-detergent fibre & 348 & 4.0 & 626 & $3 \cdot 1$ & 761 & 3.5 & 823 & 1.2 \\
\hline Acid-detergent fibre & 254 & 3.5 & 368 & 1.9 & 441 & $1 \cdot 1$ & 524 & 1.4 \\
\hline Crude protein & 172 & $1 \cdot 1$ & 63.1 & 1.5 & 64.8 & 0.7 & 28.6 & 0.7 \\
\hline Gross energy (MJ/kg DM) & $17 \cdot 6$ & 0.22 & $17 \cdot 4$ & 0.24 & 17.5 & 0.22 & $17 \cdot 3$ & 0.28 \\
\hline
\end{tabular}


donkeys and four 6-10-year-old gelding Welsh-cross ponies (Tables 2 and 3) were housed in individual stalls, next to each other, in a barn. The barn was open on one side so they received natural daylight. Urine was allowed to drain down channels in the floor away from the area where faeces were voided. Clean drinking water was always available from individually monitored supplies. The daily ration for these animals was divided into four equal meals and given at 08.00 , 12.00, 16.00 and 20.00 hours in deep-sided troughs to reduce spillage. Any food refusals and uneaten spillage were collected at 08.00 hours each day before fresh food was offered. Each animal was walked in hand or on a walker for $30 \mathrm{~min}$ per $\mathrm{d}$. Each day, animals receiving the ad libitum treatments were offered feed in excess of the previous day's intake (about 120\%). The restricted intakes were based on $75 \%$ of that animal's intakes during the second and third week of each time period (the last 2 weeks of the ad libitum feeding period).

\section{Measurements and rate of passage markers}

Each animal was weighed at the start of the experiment and twice weekly thereafter to the end of the experimental period. For the first 2 weeks of each period and the fourth week (following the change to a restricted feeding level) the animals were allowed to adapt to the change in diet. During week 3 and week 5, measurements of food intake (from the amount of DM in feed and in each individual's feed refusals, with trough and floor refusals determined separately) and faecal output (using the total collection technique) were made. Mean retention times (MRT) of two indigestible food markers, Co-EDTA, a liquid-phase marker, and Cr-mordanted hay fibre (Cr-fibre), a solid-phase marker, were measured in the ruminants as described by Mathers et al. (1989) and in the equids, essentially the same, as described by Pearson \& Merritt (1991). These markers have been found to be suitable for studying rate of passage of digesta in herbivores eating high-fibre rations (for example, Udén et al. 1982). A single dose of each marker was administered at 23.00 hours on the day preceding the collection period (day 13 or day 27). Crfibre ( $80 \mathrm{~g}$ for cattle, $70 \mathrm{~g}$ for equids and $40 \mathrm{~g}$ for sheep) was pelleted and given by hand to each animal. The Cr-fibre given to the ponies and donkeys was mixed with five 'Polo' mints (Nestlé, York, UK) to increase palatability. Co-EDTA ( $120 \mathrm{ml}$ for cattle, $100 \mathrm{ml}$ for equids and $50 \mathrm{ml}$ for sheep) was given as a drench by syringe at the back of the throat. Feeding of the appropriate diet was resumed at the same time the animals had been given the markers.

Complete faecal collections were made at regular intervals from 23.00 hours on day -1 (when markers were administered) until the end of the period ( 08.00 hours on the morning of day 8). For estimation of MRT, faeces were collected from each animal at 9, 11, 13, 15, 17, 20, 23, 31, 33, 35, 37, 39, 41, $46,54,57,60,64,69,80,84,88,93,104,112,128,136,152$, 160 and $176 \mathrm{~h}$ after marker administration. Individual faecal collections were weighed, thoroughly mixed and a subsample taken for the determination of DM and marker concentrations. A further sample, $2 \%$ by weight, from each collection was stored frozen before pooling over the $7 \mathrm{~d}$ period for each animal for subsequent analysis. All food and faecal samples were dried in a forced-draught oven at $60^{\circ} \mathrm{C}$ to constant weight and then ground through a $1 \mathrm{~mm}$ screen before analysis. Acid-detergent fibre (ADF), NDF, CP, organic matter $(\mathrm{OM})$ and gross energy were determined according to the methods reported by the Association of Official Analytical Chemists (1990).

Table 2. Starting and finishing live weight $(\mathrm{kg})$ of animals (four per species of herbivore) on the experiment

\begin{tabular}{|c|c|c|c|c|c|c|c|c|}
\hline \multirow[b]{2}{*}{ Species of herbivore } & \multicolumn{2}{|c|}{ Animal 1} & \multicolumn{2}{|c|}{ Animal 2} & \multicolumn{2}{|c|}{ Animal 3} & \multicolumn{2}{|c|}{ Animal 4} \\
\hline & Start & End & Start & End & Start & End & Start & End \\
\hline Cattle & 545 & 545 & 440 & 461 & 445 & 460 & 380 & 410 \\
\hline Sheep & 50 & 50 & 55 & 57 & 49 & 51 & 42 & 40 \\
\hline Ponies & 170 & 186 & 207 & 211 & 230 & 243 & 214 & 223 \\
\hline Donkeys & 238 & 246 & 250 & 251 & 176 & 182 & 207 & 197 \\
\hline
\end{tabular}

Table 3. Changes in live weight $(\mathrm{LW} ; \mathrm{kg})$ associated with the dietary treatments of lucerne $(\mathrm{L})$, early-cut hay $(\mathrm{H} 1)$, late-cut hay $(\mathrm{H} 2)$ or barley straw $(\mathrm{BS})$ ad libitum $(\mathrm{AL})$ or restricted $(\mathrm{R})$ to about 0.75 of ad libitum intake

(Mean values and standard deviations)

\begin{tabular}{|c|c|c|c|c|c|c|c|c|}
\hline \multirow{2}{*}{$\begin{array}{l}\text { LW change for ... } \\
\text { Dietary treatment }\end{array}$} & \multicolumn{2}{|c|}{ Cattle } & \multicolumn{2}{|c|}{ Sheep } & \multicolumn{2}{|c|}{ Ponies } & \multicolumn{2}{|c|}{ Donkeys } \\
\hline & Mean & SD & Mean & SD & Mean & $\mathrm{SD}$ & Mean & SD \\
\hline L-AL & $21 \cdot 3$ & 5.0 & $2 \cdot 6$ & $2 \cdot 0$ & 1.5 & 3.7 & 0.8 & 3.0 \\
\hline L-R & $-9 \cdot 8$ & $10 \cdot 7$ & 0.3 & $1 \cdot 0$ & -0.6 & $4 \cdot 2$ & -0.5 & $5 \cdot 0$ \\
\hline $\mathrm{H} 1-\mathrm{AL}$ & 8.5 & $5 \cdot 3$ & 1.0 & 1.4 & $2 \cdot 8$ & 1.9 & 2.5 & 2.5 \\
\hline $\mathrm{H} 1-\mathrm{R}$ & -1.0 & $7 \cdot 4$ & -0.2 & 0.95 & $-1 \cdot 3$ & $5 \cdot 6$ & -2.0 & $2 \cdot 2$ \\
\hline $\mathrm{H} 2-\mathrm{AL}$ & $3 \cdot 3$ & $4 \cdot 7$ & 0.3 & 0.9 & $2 \cdot 3$ & $5 \cdot 0$ & -0.3 & 1.5 \\
\hline $\mathrm{H} 2-\mathrm{R}$ & $-14 \cdot 0$ & $16 \cdot 9$ & -0.5 & 0.6 & -2.7 & $5 \cdot 6$ & -3.5 & $6 \cdot 3$ \\
\hline BS-AL & $-9 \cdot 8$ & $9 \cdot 7$ & $-2 \cdot 1$ & 0.8 & $-3 \cdot 3$ & 3.6 & $-4 \cdot 8$ & $1 \cdot 3$ \\
\hline BS-R & -17 & $17 \cdot 8$ & $-2 \cdot 6$ & 1.3 & $-10 \cdot 8$ & $5 \cdot 8$ & -4.5 & 4.7 \\
\hline
\end{tabular}




\section{Calculations and statistical analyses}

DM intake (DMI) was calculated from measured DM consumption corrected for DM lost as refusals or spillage. Apparent digestibility coefficients were calculated from total nutrient intakes and faecal nutrient outputs over the $7 \mathrm{~d}$ collection periods. The MRT of Cr-fibre and Co-EDTA for the ruminants were calculated using two different methods: (1) the mathematical procedure first described by Blaxter et al. (1956), as reported by Grovum \& Williams (1973) and Mathers et al. (1989); (2) the calculation according to the equation:

$$
\mathrm{MRT}=\frac{\sum m_{\mathrm{i}} t_{\mathrm{i}}}{\sum m_{\mathrm{i}}}
$$

where $m_{\mathrm{i}}$ is the amount of marker excreted at time $t_{\mathrm{i}}$ after administration of the marker, with MRT measured in h (Blaxter et al. 1956). The latter was the method used to calculate MRT of the equids. In the ruminants the two methods were compared and gave values that were not significantly different from each other for the Cr-fibre and higher for Co-EDTA with method $1(P=0.04)$. In the results to allow comparison between species, the MRT calculated using the method of Blaxter et al. (1956) are reported. The Lucas principle, the regression of percentage digestible nutrient on feed nutrient content, was used to estimate the endogenous excretion and true digestibility of cell solubles (OM-NDF) and CP by each species across the forages (van Soest, 1967).

The experiment was a change-over design comparison using four Latin squares, one for each species. Level of feeding was put in the analysis as a sub-period within the Latin squares. The data obtained were subjected to an ANOVA using GENSTAT (release 6.1 2002; Lawes Agricultural Trust, Rothamsted Experimental Station, Harpenden, Bucks, UK). In the analysis, the total sum of squares was partitioned into strata representing variation between animals and periods together with an animal $\times$ period interaction. The feedinglevel effects were expressed in a further stratum period $x$ feeding level. Overall species effects were estimated and tested from the between-animal stratum (df 12). Diet effects and species $\times$ diet interaction were estimated and tested from the animal $\times$ period stratum (df 33). Feeding-level effects were estimated from the period $\times$ feeding level stratum (df 3). Residual effects of dietary treatment were tested for carry-over using covariance analysis and were not found to be significant for any of the measurements made. Analysis of statistical differences between food intakes was undertaken at the ad libitum feeding level as restricted feed intakes were targeted at 0.75 of ad libitum intake.

\section{Results}

\section{Temperature and relative humidity}

Ambient temperatures and humidities were monitored in the animal accommodation. The readings for maximum, minimum and dry bulb temperatures and relative humidity were taken daily at 10.00 hours. The mean values of the daily values recorded during each collection period $(n 7)$ were calculated. The ranges of the mean values were $17 \cdot 5-19.4^{\circ} \mathrm{C}$ for maximum daily temperature, $8 \cdot 2-11 \cdot 3^{\circ} \mathrm{C}$ for minimum daily temperature, $9 \cdot 8-14 \cdot 7^{\circ} \mathrm{C}$ for dry bulb temperature at 10.00 hours and $80-90 \%$ for relative humidity at 10.00 hours.

\section{Period effects}

The experimental period lasted for 20 weeks, during which time each animal received each dietary treatment for a 5week period. The amount of experimental variation that could be accounted for by time-period effects (i.e. time of feeding relative to the time from the start of the experiment) was not significant.

\section{Live-weight change}

During the experiment the three lighter cattle gained weight, which suggested that they may have still been growing, and given their starting live weights (LW) and ages this would appear so. Three of the ponies also gained weight over the time of the experiment, but given their ages the changes seemed probably to be due to changes in body condition, rather than size (Tables 2 and 3). Animals generally showed a more positive LW change on the ad libitum feeding level than on the restricted feeding on all forages. Animals showed an increase in LW on the ad libitum lucerne diet, but some lost weight when this diet was restricted. Animals gained weight when earlier-cut hay was fed ad libitum and maintained or showed a small increase in LW on ad libitum later-cut hay (Table 3). Intake of barley straw did not sustain LW.

\section{Food and water intake}

Food and water intakes are given in Table 4, expressed per unit metabolic $\mathrm{LW}\left(\mathrm{LW}^{0.75}\right)$ and per unit LW. Intakes of all species were highest on the lucerne hay and lowest on the straw diets. Cattle consistently consumed more feed on all treatments than the sheep when DMI was expressed per unit $\mathrm{LW}^{075}$; however, when expressed per unit LW, intake was greater for sheep than for cattle on all diets. Voluntary DMI (VDMI; expressed per $\mathrm{LW}^{075}$ and per $\mathrm{LW}$ ) of the lucerne was significantly higher by the ponies than by the donkeys. The difference in VDMI between equids was less marked on the earlier-cut hay and intakes of the later-cut hay and of the barley straw were similar by both the donkeys and ponies when expressed per $\mathrm{LW}^{075}$ but lower in the donkeys when expressed per LW. When comparing the equids with the ruminants the differences between species in VDMI were greatest on the lucerne (the lowest-fibre highest-CP forage) and least on the barley-straw diet (the highest-fibre lowest-CP forage). Donkeys showed the least fluctuation in daily VDMI per $\mathrm{LW}^{075}$ across the forages than the other herbivores, eating least of the lucerne, but having a similar VDMI of the straw as did the cattle and ponies. The restricted level of feeding was targeted to 0.75 of ad libitum intake.

Species and diet had a significant effect on water consumption expressed per unit DM eaten and per unit LW. The donkeys and sheep had lower water intakes expressed per unit $\mathrm{DM}$, and per unit LW than the cattle and ponies on most of the diets (Table 4). All species tended to have lowest water consumption per unit DM on the hay diets, with water intakes on the lucerne diets and straw diets being notably greater per 


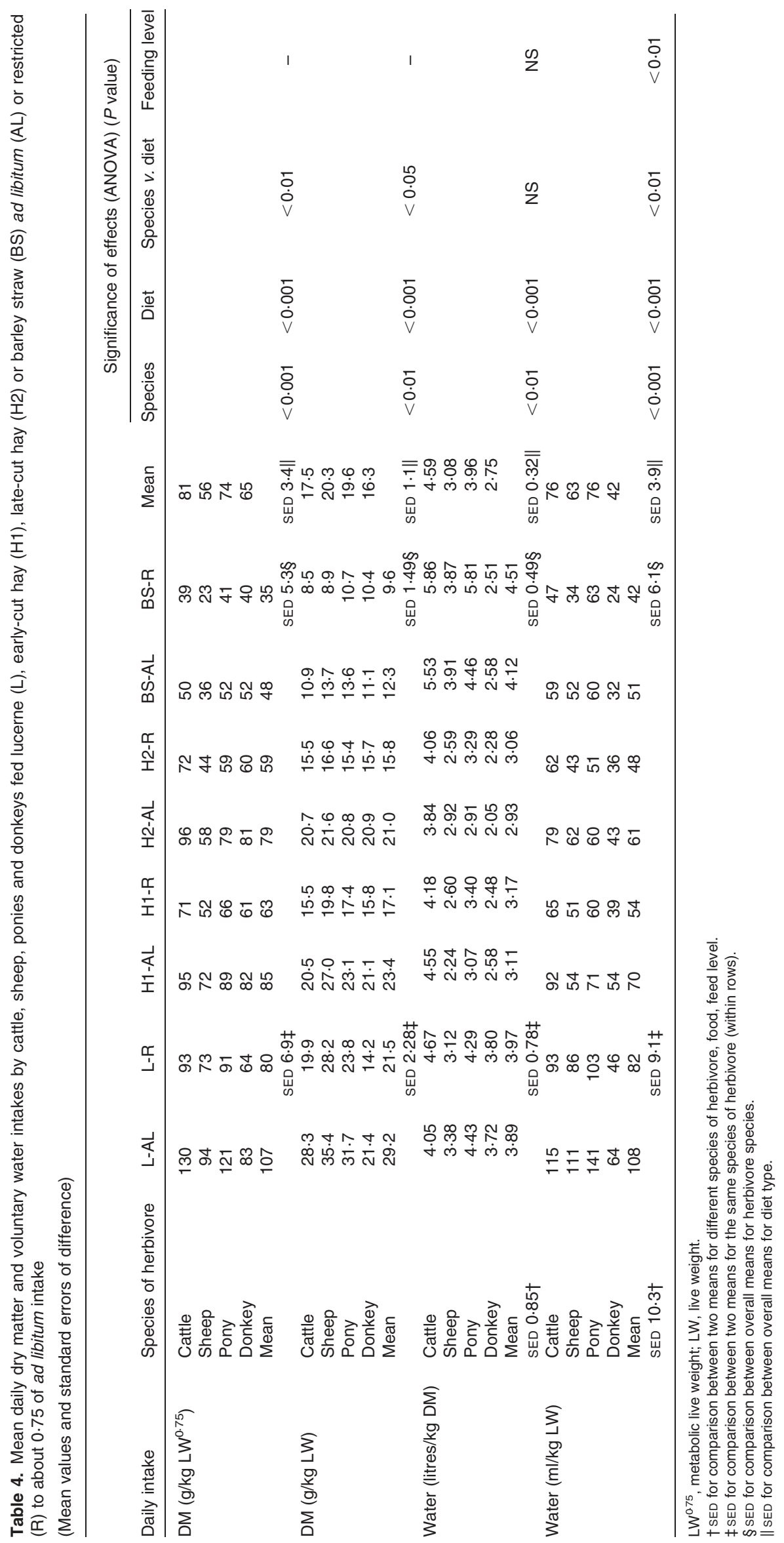


unit DM consumed, except in the donkeys on the straw diet where water consumption remained similar to that on the hay diets (Table 4). Water intakes per unit LW were highest on the lucerne diets in all species. The lowest water intakes per unit LW were seen in the donkeys on the straw diets (Table 4).

\section{Apparent digestibility of nutrients}

The ruminants had significantly $(P<0 \cdot 001)$ higher apparent digestibilities for the DM and OM components of the forages (Table 5) compared with those measured in equids on the hay and straw diets, with apparent digestibilities tending to be higher on the restricted diets than when given ad libitum (although overall effect of feeding level was not significant). However, the DM digestibility of the ad libitum-fed straw diet by the donkeys $(0.49)$ was similar to that of the ruminants ( 0.49 cattle, 0.51 for sheep), while those for the ponies on both ad libitum and restricted-fed straw were much lower $(0.26$ and 0.36 respectively) than seen in the other species at either feeding level. All species showed the highest DM and OM digestibilities on the lucerne diet, with the ponies digesting the DM and $\mathrm{OM}$ more effectively than the ruminants did. Ponies showed more fluctuation in apparent DM and OM digestibilities across the forages than the other herbivores, having the highest DM and OM digestibilities on the lucerne diets but the lowest DM and OM digestibilities on the straw diets (Table 5).

Apparent digestibility of $\mathrm{CP}$ was higher on the high-CP low-fibre lucerne diet than on the hay diets, with low or negative digestibilities recorded on the low-CP high-fibre-straw diets in all species. The cattle had the lowest and the ponies the highest $\mathrm{CP}$ digestibilities of the lucerne diets, with values being higher on the restricted feeding level than on the ad libitum feeding in all species. On the hay diets the donkeys showed the highest $\mathrm{CP}$ digestibilities of the species (Table 5).

Digestibility of ADF was higher in the ruminants than in the equids on all diets, the exception being the ADF digestibility of the restricted lucerne diet by the ponies, which was comparable with that seen in the ruminants. Cattle tended to have higher ADF digestibilities than sheep on the lucerne and hay diets and ponies had higher ADF digestibilities than donkeys on these diets. However, on the barley-straw diet the ruminants were similar, and the donkeys had higher ADF digestibilities than the ponies (Table 5). No significant effect of diet was seen on ADF digestibility, although ADF digestibilities varied across forages with the highest seen most consistently in the late-cut hay. Feeding level seemed to have a greater effect on ADF digestibility in the equids than in the ruminants, with the ponies having higher digestibilities of $\mathrm{ADF}$ on the restricted diets than when the forages were offered ad libitum. In donkeys the opposite effect was apparent with higher digestibilities of ADF on the ad libitum diets than on the restricted diets. However, none of these effects of feeding level were significant.

Digestibility of NDF was higher in the ruminants than in the equids on all diets. Cattle tended to have higher NDF digestibilities than sheep, except on the barley-straw diets and the ad libitum lucerne where digestibilities of NDF were similar. Donkeys showed higher NDF digestibilities than ponies on the lucerne and barley-straw diets, but differences in NDF digestibility in these two species were reversed on the earlycut-hay diets and absent on the late-cut hay. Significant effects of diet $(P<0 \cdot 01)$ were seen on NDF digestibility, with the highest seen when the late-cut hay was fed and the lowest when the lucerne was given. No consistent effect of feeding level was observed on NDF digestibilities across species (Table 5).

Applying the Lucas principle (van Soest, 1967), the association of digestible protein $(y ; \mathrm{g}$ digestible protein per $100 \mathrm{~g}$ DMI) to CP intake ( $x$; g CP per $100 \mathrm{~g}$ DMI) across all forages for cattle was described by the equation $y=0.854 x-2.45\left(R^{2}\right.$ $0.98)$, for sheep by the equation $y=0.910 x-3.32\left(R^{2} 0.99\right)$, for ponies by the equation $y=0.983 x-3.72\left(R^{2} 0.98\right)$ and for donkeys by the equation $y=0.866 x-3.02\left(R^{2} 0.98\right)$. These equations estimate that the metabolic faecal protein excretion for cattle, sheep, ponies and donkeys was 2.45 , $3.32,3.72$ and $3.03 \mathrm{~g}$ per $100 \mathrm{~g}$ DMI, respectively. Estimated true protein digestibilities were $0.85,0.91,0.88$ and 0.86 for cattle, sheep, ponies and donkeys respectively.

The association of cell solubles (OM-NDF) $(y$; g cell solubles per $100 \mathrm{~g}$ DMI) to cell soluble intake $(x$; g OM-NDF per $100 \mathrm{~g}$ DMI) across all forages for cattle was described by the equation $y=0.968 x-11.0\left(R^{2} 0.98\right)$, for sheep by the equation $y=1.03 x-12.36\left(R^{2} 0.98\right)$, for ponies by the equation $y=0.973 x-20.17\left(R^{2} 0.75\right)$ and for donkeys by the equation $y=0.966 x-6 \cdot 24\left(R^{2} 0 \cdot 98\right)$. These equations estimate that the endogenous excretion of DM for cattle, sheep, ponies and donkeys was 11.0, 12.4, 20.2 and $6.24 \mathrm{~g}$ per $100 \mathrm{~g}$ DMI, respectively. Estimated average true digestibility of cell solubles for forages was $0.97,1.00,0.97$ and 0.97 for cattle sheep, ponies and donkeys, respectively.

\section{Mean retention time of feed residues}

These data are reported in Table 6. In all cases, Cr-fibre $(P<0 \cdot 01)$ passed through the gastrointestinal tract of equids more quickly than through the gastrointestinal tract of ruminants, with cattle having the highest MRT of Cr-fibre and donkeys having the lowest MRT on each diet. The exception to this was the barley-straw diet. On this diet donkeys showed a longer MRT than the ponies did.

Diet effects on MRT of Co-EDTA through the digestive tract of the different herbivores were less marked than for the MRT of Cr-fibre. Co-EDTA generally passed through the gastrointestinal tract more quickly in equids than ruminants on the forage diets. The exception was the donkeys on the straw diets. The sheep tended to have a higher MRT for Co-EDTA in the gastrointestinal tract than did the cattle.

Diet had a significant effect on MRT of Cr-fibre and CoEDTA, with the longer MRT being seen on the barley-straw diet for donkeys and ruminants. In the ponies the opposite effect was seen, with the longest MRT seen on the lucerne diets, although not significant. Longer MRT of fibre were seen in all species when the diets were fed in restricted amounts than when they were fed ad libitum, although the effect of feeding level was not significant (Table 6). Effects of feeding level on rate of passage of Co-EDTA were less marked, with some animals having similar rates of passage of Co-EDTA at both feeding levels, and some showing faster rates of passage on the restricted diets (for example, 


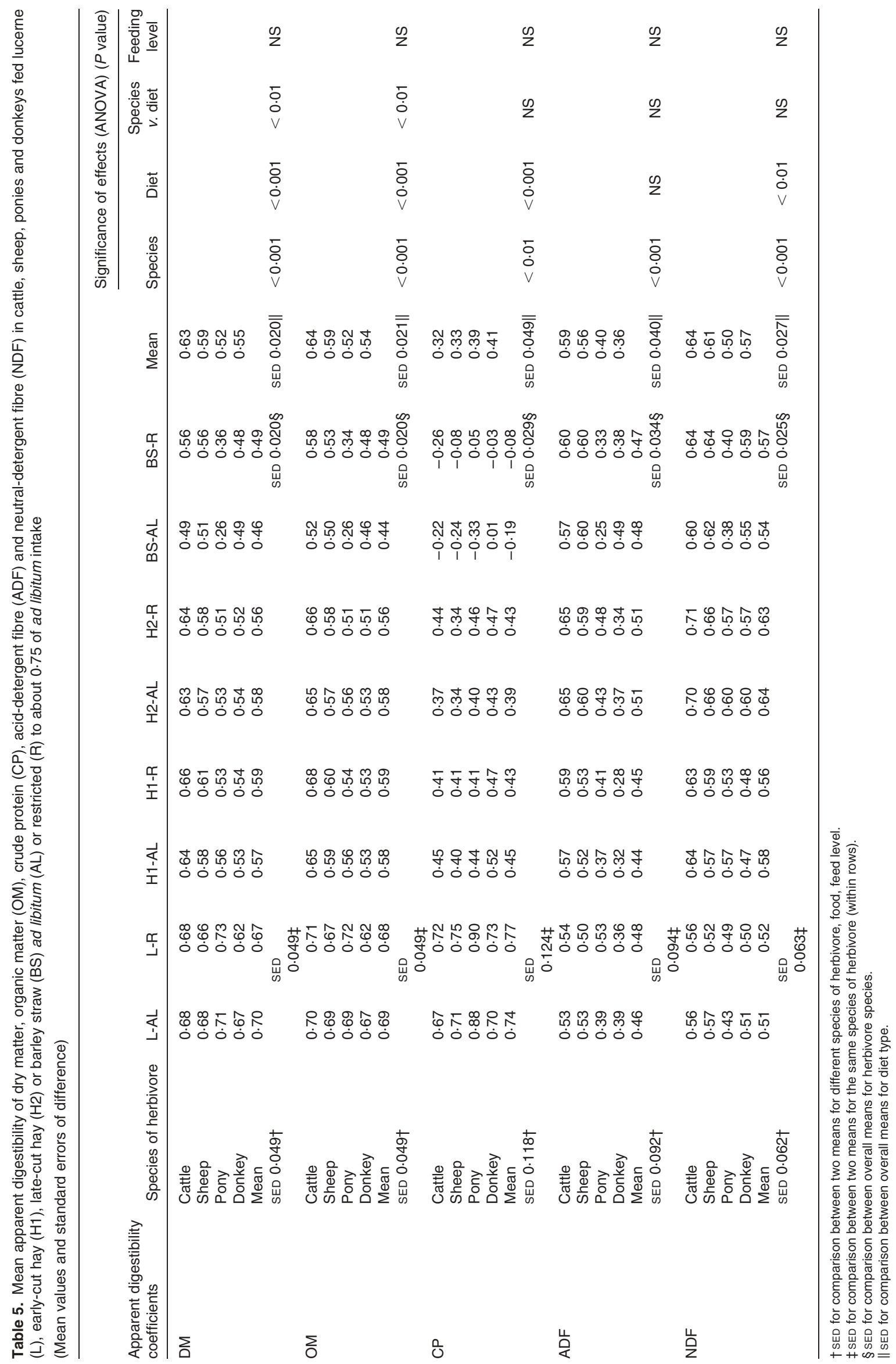


cattle offered the lucerne diet); however, again the differences seen in rate of passage of Co-EDTA across feeding level were not significant (Table 6).

\section{Discussion}

Daily VDMI of the four feed types by the four species in the present experiment were generally within the range of results reported in other studies of ad libitum feeding of conserved forages by these herbivores. Some differences were seen on the lucerne diets. Daily VDMI of the dehydrated lucerne by the cattle $\left(130 \mathrm{~g} / \mathrm{kg} \mathrm{LW}^{0.75}\right)$ were higher than those reported for dried lucerne pellets $\left(114 \mathrm{~g} / \mathrm{kg} \mathrm{LW} \mathrm{LW}^{075}\right)$ and lucerne hay $\left(121 \mathrm{~g} / \mathrm{kg} \mathrm{LW}^{075}\right)$ by Cymbaluk (1990). Similarly the sheep in the present experiment showed higher VDMI of the dehydrated lucerne $\left(94 \mathrm{~g} / \mathrm{kg} \mathrm{LW} \mathrm{LW}^{075}\right)$ than those reported by Dulphy et al. $\left(1997 a ; 62-70 \mathrm{~g} / \mathrm{kg} \mathrm{LW}^{075}\right)$ and de Vega et al. (2000; $\left.50-76 \mathrm{~g} / \mathrm{kg} \mathrm{LW}^{0.75}\right)$ for sheep consuming lucerne hays.

Values for VDMI of ponies on the lucerne $(121 \mathrm{~g} / \mathrm{kg}$ $\left.\mathrm{LW}^{0.75}\right)$ were within the range $\left(88-138 \mathrm{~g} / \mathrm{kg} \mathrm{LW}^{0.75}\right)$ reported for dried lucerne pellets, cubes or wafers (Haenlein et al. 1966; Cymbaluk, 1990; Todd et al. 1995) and the range $\left(75-122 \mathrm{~g} / \mathrm{kg} \mathrm{LW} \mathrm{LW}^{0.75}\right)$ for lucerne hays (Haenlien et al. 1966; Cymbaluk, 1990; Todd et al. 1995; Crozier et al. 1997; Dulphy et al. 1997a,b). Daily VDMI of the dehydrated lucerne by the donkeys $\left(83 \mathrm{~g} / \mathrm{kg} \mathrm{LW}^{0.75}\right)$ were within the range reported in donkeys consuming grass and grass-legume hay mixtures $\left(67-88 \mathrm{~g} / \mathrm{kg} \mathrm{LW}{ }^{075}\right.$; Pearson \& Merritt, 1991; Tisserand et al. 1991; Mueller et al. 1994).

VDMI of the two hays by the cattle $\left(95-96 \mathrm{~g} / \mathrm{kg} \mathrm{LW}^{075}\right)$, sheep $\left(58-74 \mathrm{~g} / \mathrm{kg} \mathrm{LW}^{0.75}\right)$, ponies $\left(79-89 \mathrm{~g} / \mathrm{kg} \mathrm{LW}^{0.75}\right)$ and donkeys $\left(81-82 \mathrm{~g} / \mathrm{kg} \mathrm{LW}^{0.75}\right)$ were within the range of DMI of grass hays reported in the literature for these species (for example, Udén \& Van Soest, 1982; Cymbaluk, 1990; Pearson \& Merritt, 1991; Dulphy et al. 1997a). Intakes of the barley straw by the cattle $\left(50 \mathrm{~g} / \mathrm{kg} \mathrm{LW}{ }^{075}\right)$ were in agreement with dry forage intakes seen in dairy breeds (Taylor et al. 1986). VDMI of barley straw by sheep $\left(36 \mathrm{~g} / \mathrm{kg} \mathrm{LW}^{075}\right)$ were similar to intakes by sheep of molassed wheat straw $\left(33 \mathrm{~g} / \mathrm{kg} \mathrm{LW}^{075}\right.$; Ouedraogo \& Tisserand, 1996). VDMI of the barley straw by the donkeys and ponies $\left(52 \mathrm{~g} / \mathrm{kg} \mathrm{LW}^{075}\right)$ were similar to intakes reported of wheat-straw diets by donkeys and ponies (53 g DM/kg LW ${ }^{075}$; Tisserand et al. 1991) and supplemented maize stover diets by donkeys $\left(54 \mathrm{~g} \mathrm{DM} / \mathrm{kg} \mathrm{LW}^{075}\right.$; Vall et al. 2003) The results in the present experiment support previous observations that on ad libitum conserved lucerne and grass hays adult domestic equids and ruminants can obtain enough feed to meet requirements for maintenance and even some gain. Restricting the intake of the hay and lucerne forage to about 0.75 of ad libitum intake resulted in weight loss in the growing cattle and reduced gain or small losses in the other livestock. On the straw diets intake of nutrients was insufficient to meet requirements.

Differences in intake and digestibility of the different forages are to be expected as they differ in their physical form, in their content of indigestible and digestible fibre, and in their CP content, all of which have been shown to influence daily intake and digestibility of feed by ruminants and equids. The present experiment supports the well-established observations that ad libitum intakes are higher for forages low in fibre and higher in $\mathrm{CP}$ than of forages that are low in 
fibre and protein in both fore- and hind-gut fermenters. Reasons for this are complex; factors include: diet composition, palatability, comminution, rate of microbial digestibility and passage through the gut, metabolic and physiological signals associated with the presence of nutrients within the digestive tract, and signals associated with absorbed nutrients. These factors and others have been proposed as regulators of intake in ruminants and, more recently, in horses. Often the assumption has been that a factor acts independently and exclusively of other mechanisms; however, current views based on studies of feeding behaviour, diet composition and physiological factors (such as absorbed chemicals, gut hormones, the vagus nerve, specific brain nuclei, and the protein leptin; Miner, 1998) have led to the realisation that factors regulating intake do not operate in isolation but interact to determine changes in the pattern of meals which determines the daily intake of feeds (Ingvartsen \& Andersen, 2000; Baile \& Della-Fera, 2001; Cuddeford, 2002; Rhind et al. 2002; Ellis \& Hill, 2005). In the present study, intakes of the lucerne showed more variation across species than did the intakes of the straws. It is possible to speculate that extent of forage indigestibility and degree of palatability (taste, texture and smell) have had greater effects on intake of the straw diets, with animals unable to consume enough to satisfy intake, putting them in negative energy balance, than is the case on the lucerne and hay diets where metabolic or physiological factors are likely to play a more important role and the animals were generally in positive energy balance.

Comparison of the intakes of the different forages by the ruminants did show a consistent and expected correlation with the chemical parameters which have been used to predict forage intake of ruminants (NDF, $\mathrm{ADF}$ and $\mathrm{CP}$ content); however, in the equids the effect was less marked across forages. Individual equids showed considerable variation in intake on each of the forages, more so than the ruminants. That the donkeys consumed virtually the same amounts of the lucerne and grass hays regardless of differences in fibre and protein contents of the forages suggests that chemical composition is also a poor predictor of grass and legume hay intake in this species, possibly more so than in the horse. The lack of a close association between chemical composition and intake in the equids in the present study agrees with similar observations made by other workers when comparing intakes of different quality forage diets by horses (for example, Cymbaluk, 1990; Dulphy et al. 1997a). Dulphy et al. (1997b) suggested that it would be more accurate to predict intakes for horses from forage type than from the composition characteristics of ingested forages. However, Lawrence et al. (2001) did find a good relationship between NDF content of long-stem grass hays and VDMI of horses, so it would be wrong to discount chemical characteristics altogether. It is likely to be more a case of a difference in emphasis, with other factors assuming a greater importance in determining ad libitum intake of equids than is the case in ruminants. For example, organoleptic qualities of forages (taste, odour, ease of prehension) may have a greater effect on intake in horses than in ruminants, since equids seem poor at regulating their intake according to energy intake, making them prone to obesity (Cuddeford \& Hyslop, 1996). The specific mechanisms acting to regulate appetite and intake in equids have only relatively recently been studied. Ellis \& Hill (2005) have summarised current information to date. The role of many of the metabolic factors identified in other species remains to be determined in equids.

In has been suggested that the strategy adopted by horses is to eat relatively more than ruminants (Duncan et al. 1990; Illius \& Gordon, 1990), especially on high-fibre foods, because, without the delaying effect of the reticulo-omasal orifice, that selectively retains large particles in the rumen, the digesta pass relatively quickly through the fermentation zone (caecum and colon) and the equid can therefore ingest large amounts of cell-wall-rich forage. Menard et al. (2002) in comparative studies of horses and cattle grazing on wetlands found this to be true on fresh forage, with horses extracting about $50 \%$ more digestible OM than cattle per $\mathrm{d}$. An additional benefit to the equid in a free-grazing situation is that both donkeys and ponies actively select higher-quality diets than cattle (Smith \& Pearson, 2003). The faster rate of passage of digesta through the tract in the horse is thought to be associated with decreased digestibility of feed components compared with those of ruminants.

The present experiment supported these observations on strategy when forage intakes of sheep and ponies were compared and intake was expressed per unit $\mathrm{LW}^{0.75}$, but the cattle showed higher intakes per $\mathrm{LW}^{0.75}$ than the ponies on the hay and lucerne diets and similar intakes on the straw diets. This may have been because the cattle were still growing and therefore had a greater physiological drive to consume forage than the adult non-productive sheep and equids. When intakes were expressed on a LW basis, differences between species were less marked on the hay and straw diets. In the present experiment the equids generally did have lower apparent digestibilities of feed components, particularly the fibre components compared with those of the ruminants. While this may be a consequence of shorter MRT of digesta in the gut, it may be a consequence of the reduced opportunity to absorb the endproducts of microbial digestion compared with the ruminants. Caecal micro-organisms from equids are no less efficient than those from the rumen at digesting fibre (Hyslop et al. 1997), so this is less likely to be a factor accounting for the differences in digestibilities of fibre seen. Horses and donkeys masticate for less time than ruminants in the day, showing sustained intake throughout the day including nocturnal intake (Dulphy et al. 1997a; Smith, 1999), which may well contribute to differences seen in MRT and nutrient digestibilities.

True protein digestibilities obtained for the forage-fed cattle, sheep, ponies and donkeys $(0.85,0.91,0.88$ and 0.86, respectively) agreed with those previously reported for cattle, horses and sheep (Harris et al. 1972; Cymbaluk, 1990). No comparative values for donkeys were available. Estimated metabolic faecal protein values for cattle, sheep, ponies and donkeys on the forages were $2.45,3.32,3.72$ and $3.03 \mathrm{~g} / 100 \mathrm{~g}$ DMI, respectively. Values for cattle were lower than estimates by others (Petit et al. 1985), but values for ponies were within the range reported by others (Fonnesbeck, 1969; Cymbaluk, 1990).

The true digestibility of cell contents of forages in ruminants is close to $100 \%$ (van Soest, 1967). Values for equids, being hind-gut fermenters, may be lower than those of ruminants. The estimates in the present study gave similar results 
for equids and ruminants (over 0.97), suggesting that extraction of cell solubles by hind-gut fermenters is as effective as that by ruminants. The effects of comminution, and caecal and colon microbial fermentation of soluble dietary fibre (or sugars), and absorption of endproducts in the hind-gut of equids on forages would appear to be as effective as is the system of pre-gastric fermentation in the ruminant. Endogenous excretion of DM was similar for cattle and sheep (11.0 and $12.4 \mathrm{~g} / 100 \mathrm{~g}$ DMI, respectively) and similar to other observations (van Soest, 1967), but higher in ponies than in donkeys $(20.2$ and $6.24 \mathrm{~g} / 100 \mathrm{~g}$ DMI, respectively). However, the regression equations from which these values and those of the protein were derived were produced using only the values obtained in these studies. Other reports have combined information from many data points (for example van Soest, 1967; Harris et al. 1972; Weisbjerg et al. 2004) to establish the true digestibilities of forage-fed animals.

There were some results that did not fit so closely with the different feeding strategies proposed for ruminants and equids. More research is needed into the mechanisms affecting intake and digestion of forages by herbivores before these parameters can be more fully understood.

The higher intake lower digestibility strategy of equids compared with ruminants may hold for grass hays, but when it comes to the legume hays and straws other 'models' may have to be proposed. As in previous studies (Cuddeford et al. 1995; Pearson et al. 2001), donkeys appeared closer to ruminants in their abilities to digest straw diets, and regardless of level of feeding, digested the fibre in poor-quality forages more effectively than did the ponies. This may be due to their ability to recycle urea more effectively, up to $75 \%$ on wheat straw (Izraely et al. 1989), or an ability to select less fibre when given forages low in $\mathrm{N}$ (Tisserand et al. 1991), even when selection is limited, or to the relatively lower water intakes in the donkey relative to DMI compared with those in ponies which may reduce MRT compared with that of ponies. The observations from donkeys on poor forages agree with Ouedraogo \& Tisserand (1996) who found that donkeys offered feed ad libitum extracted a higher digestible $\mathrm{OM}$ intake than sheep on poor-quality forage diets.

On the lucerne diet the ponies consistently had exceptionally high digestibilities of CP. Digestibilities of DM and OM were similar to those of the ruminants on these diets and higher than those seen in the donkeys; the reason for this is not known. Cymbaluk (1990) found cattle and horses digested DM, NDF and CP from lucerne hay similarly, but values seen were lower than those seen in the present study. Lower intakes of lucerne in the donkeys than the ponies may have been due to differences in feed preferences, but choice preference tests would be necessary to establish whether this is the case.

The apparently greater MRT of the Co-EDTA in the ponies compared with that of the Cr-fibre suggests that some of the liquid phase of the digesta may have been selectively retained in the digestive tract in these animals, which was unexpected. Alternatively, giving the $\mathrm{Cr}$-fibre in pelleted form, although with the forage, may have led to an increased rate of passage of this marker through the gastrointestinal tract. This has not, however, been observed in previous studies of equids using the same techniques in this laboratory (Cuddeford et al. 1995; Pearson et al. 2001).

\section{Conclusions}

Although ruminants and equids seemingly employ different strategies to obtain nutrients from forage diets, nutrient intake on ad libitum lucerne or average temperate grass-hay diets is sufficient to meet or exceed maintenance requirements. When feed intake is restricted the better digestibilities of feed components, particularly fibre, by the ruminants may give them nutritional advantages over equids. The higher digestibility of the diet components by the donkeys compared with the ponies on straw diets regardless of feeding level gives them an advantage over ponies where forage quality is poor; however, all species were unable to sustain LW on the barley-straw diets. Intake and digestion of lucerne by ruminants and equids are such that differences in utilisation of the forage between these fore- and hind-gut fermenters is small. Feeding forage at levels of about 0.75 of ad libitum intake had no significant effect on digestibility of feed components.

\section{References}

Allen MS (2000) Effects of diet on short-term regulation of feed intake by lactating cattle. J Dairy Sci 83, 1598-1624.

Association of Official Analytical Chemists (1990) Official Methods of Analysis of the Association of Analytical Chemists, 15th ed. Arlington, VA: Association of Official Analytical Chemists.

Baile CA \& Della-Fera MA (2001) The nature of the control of feed intake and regulation of energy balance: recent advances. Rec Res Dev Endocr 2, 387-395.

Batista HAM, Autrey KM \& Von Tiesenhausen IMEV (1982) Comparative in vitro digestibility of forages by buffalo, zebu and Friesian cattle. J Dairy Sci 65, 746-748.

Blaxter KL, Graham NMc \& Wainman FW (1956) Some observations on the digestibility of food by sheep and on related problems. Br J Nutr 10, 69-91.

Crozier JA, Allen VG, Jack NE, Fontenot JP \& Cochran MA (1997) Digestibility, apparent mineral absorption and voluntary intake by horses fed lucerne, tall fescue and caucasian bluestem. J Anim Sci 75, $1651-1658$.

Cuddeford D (2002) Voluntary food intake by horses. In Nutrition of the Performance Horse, EAAP Publication, no. 111, pp. 89-100 [V Julliand and W Martin-Rosset, editors]. Wageningen, The Netherlands: Academic Press.

Cuddeford D \& Hyslop JJ (1996) Intake and digestibility of a high fibre concentrate offered ad libitum to ponies and donkeys. In Proceedings of the 47th Annual Meeting of EAAP, Lillehammer, Norway, p. 296 [JAM van Arendoct, editor]

Cuddeford D, Pearson RA, Archibald RF \& Muirhead RH (1995) Digestibility and gastro-intestinal transit time of diets containing different proportions of lucerne and oat straw given to thoroughbreds, Shetland ponies, Highland ponies and donkeys. Anim Sci 61, 407-417.

Cymbaluk NF (1990) Comparison of forage digestion by cattle and horses. J Anim Sci 70, 601-610.

de Vega A, Gasa J, Guada JA \& Castrillo C (2000) Frequency of feeding and form of lucerne hay as factors affecting voluntary intake, digestibility, feeding behaviour, and marker kinetics in ewes. Aust J Agric Res 51, 801-809.

Dulphy JP, Jouany JP, Martin-Rosset W \& Theriez M (1994) Comparative study of intake and digestibility of forages in herbivores - a review. Ann Zootech 43, 11-32.

Dulphy JP, Martin-Rosset W, Dubroeucq H, Ballet JM, Detour A \& Jailler M (1997a) Compared feeding patterns in ad libitum intake of dry forages by horses and sheep. Livest Prod Sci 52, 49-56. 
Dulphy JP, Martin-Rosset W, Dubroeucq H, Ballet A \& Jailler M (1997b) Evaluation of voluntary intake of forage trough-fed to light horses. Comparison with sheep. Factors of variation and prediction. Livest Prod Sci 52, 97-104.

Duncan P (1980) Time budgets of Camargue horses. Behav 72, $26-48$.

Duncan P, Foose TJ, Gordon IJ, Gakahu CG \& Lloyd M (1990) Comparative nutrient extraction from forages by grazing bovids and equids: a test of the nutritional model of equid/bovid competition and coexistence. Oecologia 84, 411-418.

Ellis AD \& Hill J (2005) Nutritional Physiology of the Horse. Nottingham, UK: Nottingham University Press.

Fonnesbeck PV (1969) Partitioning the nutrients of forages for horses. J Anim Sci 28, 624-633.

Grovum WL \& Williams VJ (1973) Rate of passage of digesta in sheep. 4. Passage of marker through the alimentary tract and the biological relevance of rate constants derived from the changes in concentration of marker in faeces. Br J Nutr 30, 313-329.

Haenlein GFW, Holdren RD \& Yoon YM (1966) Comparative response of horses and sheep to different physical forms of lucerne hay. J Anim Sci 25, 740-743.

Harris LE, Kearl LC \& Fonnesbeck PV (1972) Use of regression equations in predicting availability of energy and protein. J Anim Sci 35, 658-680.

Hoffman RR (1989) Evolutionary steps of ecophysiological adaptation and diversification of ruminants: a comparative view of their digestive system. Oecologia 78, 443-457.

Hyslop JJ, Jessop NS, Stefansdottir GJ \& Cuddeford D (1997) Comparative degradation in situ of four concentrate feeds in the caecum of ponies and the rumen of steers. In Proceedings of the 15th Equine Nutrition and Physiology Symposium, Ramada Plaza, Fort Worth Texas, USA, pp. 116-117. Savoy, IL: The Equine Nutrition and Physiology Society.

Illius AW \& Gordon I (1990) Constraints on diet selection and foraging behaviour in mammalian herbivores. In Behavioural Mechanisms of Food Selection, pp. 157-181 [RN Hughes, editor]. Berlin: Springer-Verlag.

Ingvartsen KL \& Andersen JB (2000) Integration of metabolism and intake regulation: a review focusing on periparturient animals. J Dairy Sci 83, 1573-1597.

Isac MD, Garcia MA, Aguilera JF \& Alcaide EM (1994) Comparative study of nutrient digestibility, kinetics of digestion and passage and rumen fermentation pattern in goats and sheep offered medium quality forages at the maintenance level of feeding. Arch Anim Nutr 46, 37-50.

Izraely H, Chosniak I, Stevens CE \& Shkolnik A (1989) Energy digestion and nitrogen economy of the domestic donkeys (Equus asinus asinus) in relation to food quality. J Arid Env 17, 97-101.

Lawrence ACSt, Lawrence LM \& Coleman RJ (2001) Using an empirical equation to predict voluntary intake of grass hays by mature equids. In Proceedings of the 17th Equine Nutrition and Physiology Symposium, Kentucky USA, pp. 99-100, Lexington, Kentucky, USA: The Equire Nutrition and Physiology Society.

Mathers JC, Baber RP \& Archibald RF (1989) Intake, digestion and gastrointestinal transit time in Asiatic buffaloes and Ayrshire cattle given two contrasting diets and housed at 20 and 33 C. J Agric Sci (Camb) 113, 211-220.

Menard C, Duncan P, Fleurance G, Georges JY \& Lila M (2002) Comparative foraging and nutrition of horses and cattle in European wetlands. J Appl Ecology 39, 120-133.

Miner JL (1998) Recently identified signals for feed intake regulation. J Anim Sci 81, Suppl. 1, 123.
Mueller PJ, Hintz HF, Pearson RA, Lawrence PR \& van Soest PJ (1994) Voluntary intake of roughage diets by donkeys. In Working Equids, pp. 137-148 [M Bakkoury and A Prentis, editors]. Rabat, Morocco: Actes Editions.

Ouedraogo T \& Tisserand JL (1996) Comparative study of forage utilisation between donkeys and sheep. Ann Zootech 45, 437-444.

Pearson RA, Archibald RF \& Muirhead RH (2001) The effect of forage quality and level of feeding on digestibility and gastrointestinal transit time of oat straw and lucerne given to ponies and donkeys. Br J Nutr 85, 599-606.

Pearson RA \& Merritt JB (1991) Intake, digestion and gastro-intestinal transit time in resting donkeys and ponies and exercised donkeys given ad libitum hay and straw diets. Equine Vet $J \mathbf{2 3}$, 339-343.

Petit HV, Seoane JR \& Filpot PM (1985) Digestibility and voluntary intake of forages fed as hay or wilted silage to beef steers. Can J Anim Sci 65, 879-889.

Rhind SM, Archer ZA \& Adam CL (2002) Seasonality of food intake in ruminants: recent developments in understanding. Nutr Res Rev 15, 43-65.

Smith DG (1999) The impact of grazing time allowance on the dry matter intake and foraging behaviour of cattle and donkeys managed under traditional african grazing systems. PhD Thesis, Centre For Tropical Veterinary Medicine, University of Edinburgh.

Smith DG \& Pearson RA (2003) Factors affecting the survival of donkeys in semi-arid regions of sub-Saharan Africa. In Fourth International Colloquium on Working Equids, Proceedings of an International Colloquium, Al Baath University, Hama, Syria pp. 284-295, [RA Pearson, D Fielding and D Tabbaa, editors]. London: Society for the Protection of Animals Abroad.

Taylor SCS, Moore AJ \& Thiessen RB (1986) Voluntary food intake in relation to body weight among British breeds of cattle. Anim Prod 42, 11-18.

Tisserand JL, Faurie F \& Toure MA (1991) A comparative study of donkey and pony digestive physiology. In Donkeys, Mules and Horses in Tropical Agricultural Development, pp. 67-72 [D Fielding and RA Pearson, editors]. Edinburgh: Centre for Tropical Veterinary Medicine, University of Edinburgh.

Todd LK, Sauer WC, Christopherson RJ, Coleman RJ \& Caine WR (1995) The effect of feeding different forms of lucerne on nutrient digestibility and voluntary intake in horses. J Anim Physiol Anim Nutr 73, 1-8.

Udén P, Rounsaville TR, Wiggans GR \& van Soest PJ (1982) The measurement of liquid and solid digesta retention in ruminants, equids and rabbits given timothy (Phleum pratense) hay. $\mathrm{Br} J$ Nutr 48, 329-339.

Udén P \& van Soest PJ (1982) Comparative digestion of timothy (Phleum pratense) fibre by ruminants, equines and rabbits. $\mathrm{Br} J$ Nutr 47, 267-272.

Vall E, Abakar O \& Lhoste P (2003) Adjusting the feed supply of draught donkeys to the intensity of their work. In Working Animals in Agriculture and Transport. EAAP Technical Series, no. 6, pp. 79-91 [RA Pearson, P Lhoste, M Saastamoinen and W Martin-Rosset, editors] Wageningen, The Netherlands: Academic Press.

van Soest PJ (1967) Development of a comprehensive system of feed analyses and its application to forages. J Anim Sci 26, 119-128.

van Soest PJ (1994) Nutritional Ecology of the Ruminant. Ithaca, NY: Cornell University Press.

Weisbjerg MR, Hvelplund T \& Søegaard K (2004) Prediction of digestibility of nutrient detergent solubles using the Lucas principle. J Anim Feed Sci 13, Suppl. 1, 239-242. 